\title{
A TÁVLATOK ÉS A TÉRÉRZÉKELÉS ÖSSZEFÜGGÉSE BUDAPEST DUNAI VÁROSKÉPÉBEN
}

\author{
SZABÓ JULIANNA \\ $\mathrm{PhD}$, egyetemi docens. Budapesti Müszaki és Gazdaságtudományi Egyetem, Urbanisztika Tanszék. \\ 1111 Budapest, Mủegyetem rkp. 3. K II. 93. Tel.: (+36-1) 463-3847. E-mail: szabo.juli@urb.bme.hu
}

\begin{abstract}
Budapest városképének elemzésében jelen tanulmány elsősorban Granasztói Pál és Pogány Frigyes hagyományába illeszkedve, azt térben kibővítve és dinamizálva, a városhasználat mai jellegzetességeit figyelembe véve, az időközben kidolgozott vizuális érzékelési elméletek segítségével négy szinten gondolja tovább Budapest dunai városképének fejlődését, fejlesztését:

- A látás fiziológiája alapján és a proxemika analógiájaként bevezeti a városban az építészeti, a városépítészeti, illetve a tájképi érzékelés fogalmát, definiálva annak távolságát és leírva jellegzetességeit. Elemzi a budapesti Duna-part kiépülését a különböző érzékelési távlatok függvényében.

- A térérzékelés fiziológiája és pszichológiája alapján elemzi a városi kontextusban szerepet játszó mélységi információs forrásokat az érzékelés távlatának függvényében. Kiemeli a budapesti dunai látkép érzékelésében jelentős információs forrásokat.

- Történeti és kortárs forgalmi adatok alapján leírja a budapesti dunai városkép elsődleges használói célcsoportját, annak érzékelési helyzetét.

- Mindezek segítségével körvonalazza azokat a követelményeket, amelyek az építészeti alapú hagyományból kilépő Duna-parti szabályozás előtt állnak, figyelembe véve a történeti beépítésű partszakaszokat csakúgy, mint a további fejlődés előtt álló Duna-partokat.
\end{abstract}

Kulcsszavak: Budapest, Duna, építészet, városkép, tájkép, proxemika, térérzékelés

A Duna Budapest városszerkezetének és városképének is szervező ereje, egyediségének kétségtelen alapja. Természetesen számtalan várost ismerünk, amelyek szerkezetét egy központi folyóvíz határozza meg. Budapest speciális geomorfológiai adottsága, a történeti városfejlődés szerencsésebb vagy kevésbé szerencsés fordulatai, a folyó intenzív használata és vízmérnöki kiépítése oda vezettek, hogy a Duna a budapesti városépítészet és városfejlesztés kulcskérdése lett.

A folyó menti fejlesztéseknek számos közlekedésszervezési, tulajdonjogi, ingatlanpiaci, környezetvédelmi stb. vonatkozása van, azonban ez a cikk egyetlen speciális témára: a fejlesztéseknek a városképre gyakorolt hatására koncentrál. A dunai városkép egyedülálló értékének felismerése óta ugyanis minden intenzív fejlesztési periódusban felerösödik a városkép védelme körül folyó vita is, elég, ha csak a Hilton Szálloda, a pesti szállodasor, vagy legutóbb, a tervezett budai rakpartszélesítés körüli vitákra utalunk. 
Milyen beépítés engedhető meg a Duna partján? Milyen magas, milyen széles, milyen tagolású, milyen építészeti formálású? Hogyan lehet megóvni a ma már a világörökség részeként számon tartott panorámát? Milyen szabályozási elemeket kell beépíteni a főváros építészeti szabályozásába ennek érdekében?

A rendszerváltás óta a budapesti fejlesztési koncepciók egyik alapvetése a Dunapartok felértékelése, a volt parti ipari területek funkcióváltása, a városközponti funkciók kiterjesztése a Duna mentén és a kiváló környezeti adottságok kihasználása magas presztízsü lakó- és munkahelyek építésére, a zöldfelületi rendszer fejlesztésére. Az építőipar sokéves krízise után 2014-ben újra emelkedni kezdtek a budapesti ingatlanárak. A következő években újra esélyessé válik ezeknek a terveknek a megvalósulása. Beindulhatnak a külső kerületekben leállt fejlesztések, de egyre erősebb ingatlanfejlesztöi nyomás fog nehezedni a világörökségi területre is.

A főváros új szabályozási módszertan kidolgozásával és ennek a budapesti szabályozásba integrálásával kísérli megelőzni a problémákat. Első lépésként az Építész Stúdió 2014 őszén kidolgozta a budapesti Duna-partok karakterelemzését, ${ }^{1}$ amelyet Pálfy Sándor DLA a „Donau-Stadt-Landschaften” második konferenciáján mutatott be 2015 januárjában.

A karakterelemzés a dunai partok látványában négy réteget különböztet meg: az úszó müvek (pontonok, hidak, állóhajók stb.), a rakpartok, a zöld elemek, illetve az első sor beépítés homlokzatainak rétegét. Ezeket a rétegeket egyenként felvéve, elemezve, majd egymásra vetítve határozza meg a különböző partszakaszok jellemző karakterjegyeit. A karakterelemzés egy új lépcsőt jelent abban a törekvésben, amely a budapesti városkép látványát, értékét tudományos, itt analitikus alapon kísérli meghatározni.

Ez a lépcső azért is jelentős, mert a témával foglalkozó szakirodalom a kérdés érzelmi súlyához mérten meglepően szükös. Természetesen több lényeges munkát ismerünk, amelyek a dunai hidak, rakpartok, parti beépítések kialakulását tárgyalják, elsősorban technikatörténeti, építészettörténeti szemszögböl. ${ }^{2}$

A városkép esztétikai alapú elemzésének atyja, Camillo Sitte $^{3}$ nyomdokain Magyarországon Pogány Frigyes ${ }^{4}$ haladt. Ez a tradíció a hagyományos építészeti tér- és kompozícióelemzés eszköztárát alkalmazza a külső terek, építészeti együttesek esetében. Érdeme az elemzés bevezetése városépítészeti léptékben, de a budapesti látkép elemzéséhez szükséges tájképi lépték bevonása nélkül. Pogány Frigyes könyvében a budapesti látvány leírásában ugyan kilép a tájképi lépték területére ${ }^{5}$ de a formálási eszköztár példáiként a budai Vár és a pesti Belváros belső városképének jellegzetességeit elemzi. A budapesti városkép kétségtelenül legihletettebb szakírója Granasztói Pál, aki számtalan esszéjében, könyvében írta le és elemezte rendkívül

\footnotetext{
${ }^{1}$ Pálfy-Sólyom-Fialovszky 2014.

${ }^{2}$ Berza 1993, Gáll 2005, Kolundzsija 2007, Preisich 2004.

${ }^{3}$ Sitte 1889.

${ }^{4}$ Pogány 1954.

${ }^{5}$ Pogány 1954. 153-155.
} 
érzékletesen fővárosunk látképét, ${ }^{6}$ és megfogalmazta a tájépítészeti lépték jelentőségét a panorámában. Granasztói írásai azóta minden magyar városépítész fővároshoz való elkötelezettségét meghatározzák. Stílusuk azonban elsősorban képszerü, emocionális; kevéssé használják fel akár azokat a törvényszerüségeket, amelyek egy-egy építészeti együttes hatásának elemzésében már abban a korban is rendelkezésre álltak, akár a magyar, akár a nemzetközi szakirodalomban.

Ennek a tudományos eszköztárnak alapja a vizuális érzékelésről, ezen belül a mélység- vagy térérzékelésről szóló tudásunk, amelynek részleteit James G. Gibson dolgozta $\mathrm{ki}^{7}{ }^{7}$ de jelen tanulmányban a mára letisztult rendszert használjuk fel. ${ }^{8}$ Gibson munkássága úttörö volt abban a tekintetben is, hogy az észlelés folyamatát nem redukálta le a beérkező ingerek automatikus, fiziológiai érzékelésére, hanem a néző aktív szerepvállalásával lejátszódó folyamatnak tekintette, amelyet az észlelő és a környezet egységében lehet csak értelmezni. Ennek természetesen a város percepciójában különös jelentősége van, hiszen érzékleteinket az urbánus térben fokozottan befolyásolják emlékeink, tudásunk, hangulatunk, intencióink stb.

Az ily módon komplex városkép pszichológiai megközelítésének, befogadásának elemzése szempontjából meghatározó Kevin Lynch ${ }^{9}$ munkássága, aki Kepes György vizuális elméletére is támaszkodva kimutatta a mentális városképek alapvető elemeit, ezek működését a városhasználók tájékozódásában, a város olvashatóságában. Lynch módszertana tette lehetővé, hogy a városkép elemzése mérhető tudományos alapokon nyugodjék. A mentális városképeknek Lynch óta számtalan alkalmazott kutatása született, de Budapestre sajnos nem ismerünk olyan elemzést, amely értékelhető számú budapesti megkérdezésére támaszkodna - erre ez a tanulmány sem vállalkozhat.

Lynch is hangsúlyozta a városképi elemek között az utak elsődleges fontosságát a városhasználók tájékozódásában. Ezt a gondolatot viszi tovább a promenadológia tudománya, amely a város érzékelésébe a nézőpont mozgását integrálja. A sétatudomány Gordon Cullen szekvenciális látványelemzésével kezdődött, és a legteljesebb magyar elméleti kifejtését Meggyesi Tamás tanulmányábó $1^{10}$ ismerjük.

Budapest városképének elemzésében jelen tanulmány elsősorban Granasztói Pál és Pogány Frigyes hagyományába illeszkedve, azt térben kibővítve és dinamizálva, a városhasználat mai jellegzetességeit figyelembe véve, az időközben kidolgozott vizuális érzékelési elméletek segítségével négy szinten gondolja tovább Budapest dunai városképének fejlődését, fejlesztését:

- A látás fiziológiája alapján és a proxemika analógiájaként bevezeti a városban az építészeti, a városépítészeti, illetve a tájképi érzékelés fogalmát, definiálva annak távolságát és leírva jellegzetességeit. Elemzi a budapesti Duna-part kiépülését a különböző érzékelési távlatok függvényében.

\footnotetext{
${ }^{6}$ Főleg Granasztói 1980.

${ }^{7}$ Gibson 1950.

${ }^{8}$ Sekuler-Blake 2004.

${ }^{9}$ Lynch 1960.

${ }^{10}$ Meggyesi 2012.
} 
- A térérzékelés fiziológiája és pszichológiája alapján elemzi a városi kontextusban szerepet játszó mélységi információs forrásokat az érzékelés távlatának függvényében. Kiemeli a budapesti dunai látkép érzékelésében jelentős információs forrásokat.

- Történeti és kortárs forgalmi adatok alapján leírja a budapesti dunai városkép elsődleges használói célcsoportját, annak érzékelési helyzetét.

- Mindezek segítségével körvonalazza azokat a követelményeket, amelyek az építészeti alapú hagyományból kilépő Duna-parti szabályozás előtt állnak, figyelembe véve a történeti beépítésủ partszakaszokat csakúgy, mint a további fejlődés előtt álló Duna-partokat.

A mélységi információk kibontásával az analitikus módszertanú karakterelemzésnél közelebb juthatunk a városkép hatásának megértéséhez. Ugyanakkor nem szabad elfelejtenünk, hogy a látvány elemei benyomásainknak csak egy - bár lényeges részét alkotják, amelyet kiegészítenek a más érzékszerveink által közvetített információk, és értelmezési keretbe - Gibson elméletének is megfelelően - a történelem, a kultúra, ismereteink, emlékeink és hangulatunk illeszti. A teljes összefüggésrendszert leszükítve azonban jelen tanulmány csak a városkép látványára összpontosít.

Képzeletben egyenként vizsgálva a dunai városképeket, minden felvétel a természeti és az épített környezet számos eleméből áll össze. A nézőponttól függően eltolódik a kompozíció, a távlatoktól függően elmozdulnak a viszonyok, az arányok, változnak a színek és a részletgazdagság. Mindennek egyetlen kiemelt, statikus és leegyszerüsített - mert a tériséget nem visszaadó - nézetét analizálja a karakterelemzés. Az építészet és városépítészet lényege azonban a terek létrehozása. Budapest látványának drámája különös módon a térérzékelésen alapszik, egyrészt a két part rendkívül különböző morfológiájának egymásra hatása miatt, másrészt a folyam kettős kanyarulata miatt, amely a szemlélődő helyzetétől függően folyamatosan megváltoztatja a térbeli elemek egymáshoz való viszonyát a tájban. Nem tekinthetünk el hát attól, hogy Budapest dunai városképének értékelésében, védelmében elsősorban a téri viszonyokra támaszkodjunk, és ennek elemzését a térérzékelés sajátosságai alapján kíséreljük meg. Jelen tanulmányban mindebből két kérdést járunk körül: az elemek léptékét a látványban, valamint a térérzékelés és a távlatok összefüggését. Mindezt kiegészíti a városhasználók pozíciójának és dinamikájának változása a városban és az ő szubjektív érzékelésük megváltozása ennek következtében.

\section{VÁROSÉRZÉKELÉSI PROXEMIKA A BUDAPESTI DUNA-PARTON}

A hatvanas évek egyik nagy hatású fejleménye volt az építészet és a városépítészet gyakorlatában a proxemika kidolgozása. Edward T. Hall könyvében az emberek közötti kommunikáció tipikus távolságait vizsgálta, elsősorban annak függvényében, hogy az adott távolságon milyen módon teremtünk kapcsolatot a másik személlyel. Bizalmas, személyes, társasági és nyilvános távolságot különböztetett meg a környe- 
zet és a kommunikációs partner tapintási, szaglási, kinetikus, hallási és vizuális érzékelése alapján. ${ }^{11}$ A következőkben a proxemika analógiája alapján az urbánus környezet három tipikus érzékelési távolságát: az építészeti, a városépítészeti és a tájépítészeti távolság fogalmát vezetjük be, erre alapozva a budapesti tájkép elemzését. Ezek a távolságok már nem az ember és ember közötti, hanem átvitt értelemben az ember és városi környezete közötti „kommunikáció” lehetőségeit jelentik. A „kommunikáció” valójában egyoldalú, azaz a városi környezet érzékeléséről beszélünk, a távolsági tartományokból adódóan szinte kizárólag a vizuális érzékelés törvényszerüségei alapján.

Az emberi szem felépítése alapján háromféle látásról beszélünk, amelyek meghatározzák a különböző távolságokból érzékelt környezeti képeket. A legélesebb fókuszt a látógödri vagy foveális látás biztosítja, amellyel rendkívüli pontossággal tudunk egy-egy részletre fokuszálni. Ennek látószöge azonban rendkívül kicsiny, és a fokuszálás egy bizonyos távolság után gyengül. A foveális látómezőt övezi a sárgafolt látómezeje, amelynek vízszintes kiterjedése kissé nagyobb, mintegy 10-12 fok, míg a függőleges kiterjedés csak mintegy 3 fok. Ennek képe még mindig éles, de nem éri el a foveális fókusz pontosságát. Végül a harmadik zóna a periferiális látás mezeje, amely a sárgafolti látástól kifelé, a középvonaltól a vízszintes síkban mintegy 90 fokig közvetít képet az agyba. A sárgafolti látástól kifelé haladva a periferiális látás élessége és színmegkülönböztető képessége egyre csökken. Ugyanakkor ebben a térben különösen érzékenyek vagyunk a mozgó elemek érzékelésére, aminek a későbbiekben még lesz jelentősége.

Hall a proxemikában bevezetett társasági távolságot 360 centimétertől számítja, és megállapítja, hogy 9-10 méter távolságtól minden közvetlen emberi kommunikáció lehetősége megszünik. ${ }^{12} \mathrm{~A}$ városi környezet számos teoretikusa gondolta ennek alapján, hogy a humánus emberi környezetnek ezen a léptéken belül kell maradnia. Ennek megfelelően az ideális utcakeresztmetszet szélessége a 10 métert, a szegélyező épületek magassága a 3-4 szintet nem haladhatja meg.

Budapest középkori városszövete - hasonlóan a többi középkori városéhoz megfelelt ennek a követelménynek: az utcák szélessége részben máig, az épületek magassága legalábbis a klasszicista korszakáig. Egy ilyen utcában a járdán közlekedő éles látómezejébe a szemközti ház homlokzatának egy 7-8 méter széles szelete fér bele, fokuszálva azonban csak egy 2-2,5 méter átméröjü részletet, azaz egy bejáratot, kirakatot vagy erkélyt lát. A fokuszált részlet még a legfelső épületszinten is lehet: nemcsak beszélgetni lehet a legfelül lakóval, de még értelmezhetőek a koronázó párkány építészeti részletei is. Ez az építészeti érzékelés, az építészeti távolság kezdete.

A kiegyezés után Budapest Európa egyik legviharosabb urbanizációs hullámát élte át. Ez nemcsak a külvárosok kiépülését okozta, hanem azt is hozta magával, hogy a belváros eklektikus átépülése, az épületek lecserélődése 3-5 emelet magas

${ }^{11}$ Hall 1987. 160-175.

${ }^{12}$ Hall 1987. 175. 

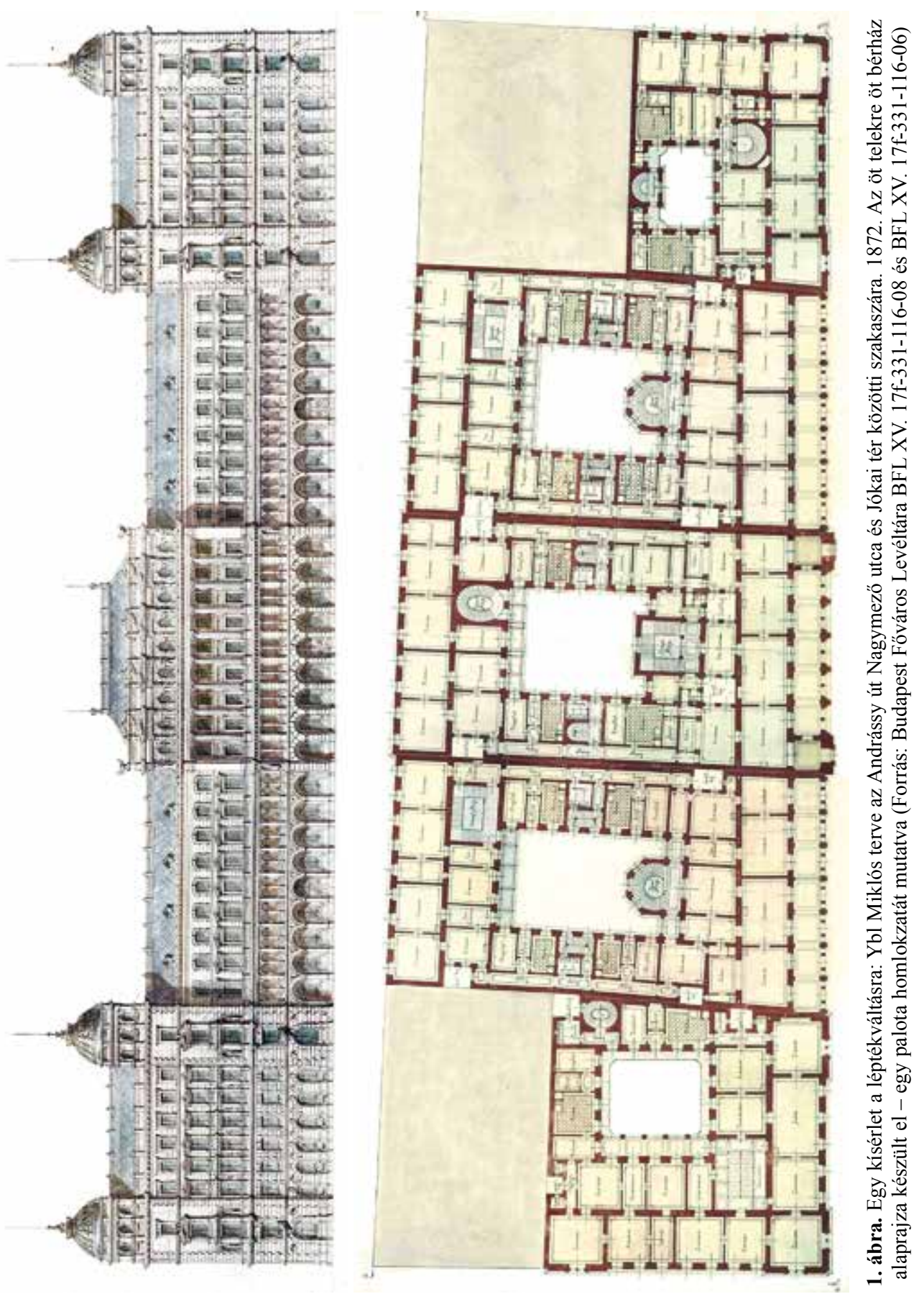
bérházakkal jórészt a középkori utcahálózat megtartásával ment végbe. A párizsi példa alapján csak néhány szélesebb utat vágtak a városszövetbe: a körutak, az Andrássy út és a mai Kossuth Lajos utca kiszélesítése számíthat ide. Ezeken a tengelyeken kívül az új, gazdagon díszített, akár 18-20 méter magas épületek gyakran 6-8 méter széles utcák mentén magasodnak.

Diákjainknak, vendégeinknek gyakran javasoljuk, hogy emeljék fel a tekintetüket a pesti belváros utcáit járva: ez a stíluskorszak az építészeti részletek hihetetlen gazdagságát produkálta. A normál járókelő azonban ritkán teszi ezt, és így az eklektikus építészet leginkább az építészeti albumokban hat. A pesti belváros lakói által megélt belső városképe intim: azt a földszinti építészeti részletek, bejáratok, boltok, utcaburkolat, reklámfelületek, köztéri bútorzat határozzák meg. Ebben az érzékelési térben ráadásul még fontos szerepe van a város hangjainak, illatainak, akár felületeinek is.

Annál élesebb a kontraszt, amikor a járókelő a 19. század végén ki- vagy átalakított egyik nagytengelyhez érkezik, és a szemben álló épületek homlokzata teljes kompozíciójában feltárul. Az Andrássy út belső szakaszainak szélessége 34, illetve 45 méter, ahogy a Nagykörúté is. A korszak tervezett városi tereinek átmérője 60-80 méter. Ebből a távolságból már az egész homlokzat az éles látómezőbe kerül, a távolság növekedésével azonban elvesznek a finom részletek. Ahogy Camillo Sitte is megállapította, a korszak egyik legfontosabb formálási problémája volt, hogy a zártsorú beépítésben a homlokzatok milyen módon tudnak lépést tartani a közterületek nagyságrendi növekedésével. ${ }^{13}$ A klasszikus építészeti elemek egyre nagyobbá váltak, végül közös motívummá álltak össze. A homlokzat textúrájának is egyre erősebbé kellett válnia, míg végül az épület tömegformálása vette át az építészeti hatás hordozójának szerepét. Ez az a távolság, ahol végződik az épített környezet építészeti érzékelésének távolsága, és kezdődik a városépítészeti lépték (1. ábra).

Budapesten azonban alig találni olyan nézőpontot, ahol a folyóparti házsor ebből az építészeti távolságból érzékelhető lenne, hiszen a házak vagy a hegyoldalak általában túl közel lépnek a szabályozott vízparthoz. A Duna-parti hídfök és terek nemcsak azért fontosak, mert ritmusukkal tagolják, mélységükkel pedig térbelivé alakítják a parti homlokzatsort, hanem azért is, mert kivételes helyzetükkel lehetővé tették néhány jó arányú és természetes müködésủ középület elhelyezését a parton. Amikor a 19. századi folyószabályozással felértékelődtek a parti telkek, a terek nagy presztízsủ nemzeti vagy magán középületeket fogadhattak be, és a Tudományos Akadémia, a Vigadó, a Gresham-palota vagy a Gellért Szálló a városi közterület léptékében értelmezhető építészeti tagolással és a városi közterülethez való szerves funkcionális kapcsolattal épülhetett fel.

Ezek azonban kivételes esetek. A rakparti házsorok homlokzatait az azonos partról a víznek háttal szemlélni még akkor is kellemetlen és bizonytalan helyzet lenne, ha megfeledkezhetnénk az autóforgalomról. Az Építész Stúdió építész szempontú és részletezettségü felvételeihez egy különleges módszerhez kellett folyamodni: hajót

${ }^{13}$ Sitte $1901.52-53$. 
bérelni és a vízről feldolgozni a parti látványt. Valójában ez a sétahajók nézőpontja, a városhasználók a parti épületeket általában a szemközti partról, valamelyik hídról vagy a folyó távolabbi kanyarulatából szemlélik. A Duna Budapesten szélesebb, mint más nagy európai metropoliszok folyói, csak a Temze Londonban vagy a Néva Szentpéterváron hasonlítható hozzá. A legszükebb keresztmetszet a Szabadság hídnál is meghaladja a 300 métert. A sürü városszövet déli végénél a Petőfi híd 500 métert, az északi végénél a Margit híd a két Duna-ággal több mint 600 métert, az Árpád híd 900 métert hidal át. ${ }^{14}$ Ezek a távolságok mindenképpen meghaladják a városépítészeti értelmezés távolságát, a tájképi érzékelés körébe tartoznak.

Ha valamelyik belső hídon indulunk Pestről Budára, körülbelül a híd közepénél lépünk ki a városépítészeti távlatból. Innen visszapillantva már egy átlagos pesti háztömb egésze a fokuszált látásba fér, a látómezőben pedig érzékelhetővé válik a tömbök és utcatorkolatok ritmusa. Ahol pedig terek törik meg a rakparti házak sorát, a tömbök mélysége is egyértelmüvé válik, és a szemlélődő számára megjelenik a város háromdimenziós szerkezete.

A Duna legkeskenyebb szakaszán, a Gellért-hegy alatt a budai rakpartra érve még a város részesének érezhetjük magunkat. A szem látómezeje a pesti tömbök egész sorát befogja már, de a foveális látás még lehetővé teszi számunkra egyes homlokzatok megkülönböztetését. Ahogy azonban felkapaszkodunk a hegyre, egyre jobban elvesztjük ezt a bensőséges érzést, és a város külső szemlélőjévé válunk. Természetesen az érzékelés több aspektusa játszik szerepet ebben a váltásban a belső és külső városkép érzékelése között, mint például a zajszint csökkenése vagy a felülemelkedés kinesztéziai tapasztalata. A legfontosabb talán mégis a vizuális érzékelés változása és az ebből adódó kognitív tapasztalat. A nézőpont emelkedésével egyre több pesti házsor jelenik meg a városképben. Az egyes épületeket azonban már nem lehet ebböl a távolságból és szögből megkülönböztetni, és a városszerkezet sem tekinthető át. A házsorok egy sajátos színű és textúrájú egészet alkotnak és a tájkép részévé válnak. Ez a távolság már a tájképi érzékelés távlata.

\section{LÉPTÉK ÉS TÁVLATOK A BUDAPESTI DUNA-PART ÉPÍTÉSZETÉBEN}

Budapest építészettörténetében a tájépítészeti lépték hasonló gondot okozott, mint az építészeti eszköztár adaptálása a 19. század közepétől megnövekedett közterületek nagyságához. A század végére az új, nagy presztízsü középületek elhelyezésére a belvárosban már nem akadt építési telek. A Duna szabályozása, a rakpartok folyamatos kiépítése azonban új fejlesztési területekhez jutatta a Fővárost. Ráadásul ezek a területek a város fejlesztési irányaiba estek, és folyóparti helyzetük megfelelt a kor reprezentációs elvárásainak. Így épült a város és a nemzet számos kiemelkedő közintézménye, mint az Országház, a Vámház, a Múegyetem központi épülete közvetlenül

${ }^{14}$ Gáll 2005. 170. 
a Duna partjára. Ránézve egy Budapest-térképre rögtön szembetünik, hogy ezeknek az épületeknek a mérete tömb léptékü vagy akár többszöröse egy szokványos pesti háztömbnek. A méreteket részben a funkciók, de föképp a nemzeti presztízs, a Béccsel való verseny indokolta. Az építészek a tömeg és a homlokzatok tagolásával tudatosan alkalmazkodtak a Duna - ezeken a helyeken már több mint 400 méter körüli - szélességének léptékéhez. ${ }^{15}$ Ezek a távlatok maguktól szállították a nagyvonalúságot. Nem véletlen, hogy az Országház képe a folyó hullámaival Budapest egyik ikonikus képévé vált. A középületek müködését azonban megnehezíti, hogy főhomlokzataik a rakpartokra nyílnak előtér és valós városi kapcsolat nélkül. Miközben a képviselők és az egyetemi hallgatók oldalsó és hátsó bejáratokon tülekednek, a pompázatos főhomlokzatok előtt elsorvadt a városi élet.

A kor építészei, a Közmunkatanács és valószínűleg a Székesfőváros közönsége számára is ekkorra egyértelművé és kézzelfoghatóvá vált a ma is gyakran hangoztatott tétel, miszerint „,a Duna Budapest föutcája”. A folyón épülő mérnöki létesítmények részben természetes módon vették fel a tájképi léptéket. Már a Lánchíd pillérkapuzatai is meghaladták a hídföknél álló korabeli épületek magasságát. Ma ritkán tünik a szemünkbe, de a folyamatos építkezések folyamán nyilvánvalóbb lehetett, hogy a budapesti rakpartok a maguk 8 méteres magasságával és 24 kilométeres hoszszával a város legnagyobb összefüggő építményét alkotják. ${ }^{16} \mathrm{~A}$ Millenniumra az akkori várostesten belül épülő két híd, a Szabadság és Erzsébet híd kapuzatai azonban már nem technikai szükségszerüségből emelkedtek ki a várossziluettből. A beadott pályázatokat elnézve felerősödhet a gyanú, hogy az elsődíjas pályamü elvetésekor és a régi Erzsébet híd végül megépített tervének kiválasztásakor a minisztérium a nagyvonalúságot - értsd kivételes nagyságot, reprezentativitást - tartotta szem előtt. ${ }^{17} \mathrm{~A}$ második világháború után még évekig állt a híd egyik hatalmas kapuzata, értelmét vesztett nagyságával a város régi dicsőségére és a háború pusztítására emlékeztetve. Az új kábelhídnak már csak a budapesti identitásba beégett kép miatt is tartania kellett ezt a léptéket.

A „dunai föutca” programba illeszkedtek a Várhegy 19. századi átépítései is. Elöször a parton elbontott házsor helyére felépült a Várkertbazár együttese, amely valódi városi élet híján soha nem vált funkcionálisan életképessé. A Mátyás-templom tornyának csúcsos újgót formájába nehéz nem belelátni a szándékot, amely a Vár kontúrját kívánta gazdagítani, megemelni a pesti nézőközönség igényei és szemlélési távolsága szerint. Hasonló a helyzet a régi Halászbástyával, amely valószínütlen és történelmietlen új ráépítést kapott. A lépcsőkkel, tornyocskákkal, mellvédekkel, szobrokkal zsúfolt új Halászbástya célja, hogy kontúrjának és reliefjének mozgalmasságával érzékelhetővé váljék Pest felől - azaz tájképi léptékben is. Hasonló logikával nőtt a királyi vár a 19. század végi átépítés során méretében és magasságában is szinte kétszeresére annak ellenére, hogy a funkcionalitást és az új arányokat már akkor és azóta is többen megkérdőjelezték.

${ }^{15}$ Pogány 1954. 174.

${ }^{16}$ Kolundzsija 2007.

${ }^{17}$ Gáll 2005. 91-93. 
Budapest dunai látképét így az első világháborúig kétféle építészeti komponálás hagyománya határozta meg: egyrészt az építészeti léptékben gondolkodás, aminek példái a pesti rakpartok házsorai, másrészt a tájképi léptékú építészet, amelyre példák az említett középületeink. Csak kivételszerüen jelent meg a városépítészeti léptékü formálás azokon a helyeken, ahol a hídfők vagy a Vigadó tér városépítés-történeti adottsága ezt lehetővé tette.

A különleges építészeti figyelem csak az akkori sürün beépített városszövet határáig tartott: a Margit hídtól a Szabadság híd vonaláig. Ezektől a hidaktól északra és délre jobbára az ipar és a vasút foglalta el a Duna-partokat. Az ipari területeket egy szórt, rendezetlen beépítés jellemezte, ezt azonban általában intenzív növényzet takarta a Duna felé. A partok karaktere a tájképi léptékben zöld volt, amit erősített a szigetek zöldfelülete is. ${ }^{18}$

A két világháború között a város csak az újlipótvárosi partszakaszt foglalta vissza az ipartól. Ez a beépítés azonban mindenféleképpen kiemelendő, hiszen talán az egyetlen városi léptékü parti kompozíció. Annak ellenére, hogy az új lakónegyedet a Margitsziget látványa eleve felértékelte, a városépítész nem elégedett meg ennyivel. A Szent István park kiszabályozása nemcsak növelte a közvetlen dunai kilátással építhető lakások számát, nemcsak olyan közös zöld közterületet hozott létre, amely máig a negyed társadalmi központja, hanem olyan léptéket is biztosított, amelyben az épületek városépítészeti léptékben érzékelhetők, értelmezhetők. Ez az a lépték, amelyben az építészeti formálásban a vonzó, bensőséges emberi környezet és a reprezentativitás követelményei egyaránt érvényesíthetők.

A Duna partjainak fejlődését a további szakaszokon az ipar követelményei határozták meg. A látvány értelmezése másodrangú marad egészen az 1990-es évek végéig, amikor a budapesti ipar összeomlása felvetette a területek konverziójának, felértékelésének lehetőségét.

A rendszerváltás után tervezett és/vagy megvalósított projektek vagy az építészeti, vagy a tájképi léptékü építészeti hagyományt folytatták.

Az első ilyen projekt a tervezett EXPO terület volt, ahol a nemzeti reprezentáció igénye, az új, déli városközpont megteremtésének gondolata és a gyors gazdasági felzárkózás reménye bombasztikus beépítési koncepciót eredményezett. Ugyan az EXPO elmaradt, de az új egyetemi területek és a millenniumi városrész alakulását meghatározta az örökölt szabályozási terv. A budai oldalon a kompozíció elvben egy központi tér köré épült. A két parti egyetemi épület szabadon álló tömege azonban nem képes definiálni ezt a teret, amelyet funkcionálisan tovább ront - a kiépült tömegközlekedés és szint alatti parkolók hiányában - az épületek környékét ellepö parkoló autók serege. Ily módon az egyetemi épületek a Müegyetem és a Közgáz épületének hagyományát folytatják: hatalmas, monolitikus, tájképi léptékü, egymással konkuráló tömegükkel, azonban az elödök plasztikus tömeg- és homlokzati formálása nélkül.

\footnotetext{
${ }^{18}$ Garay-Benkő 2015, Kissfazekas-Illyés-Gurdon 2015, Romaniak-Skaliczki-Szabó 2015.
} 
A pesti oldalon a lakó- és irodaházak sora a pesti zártsorú beépítés hagyományát folytatják. Magasabb beépítésük és homlokzati formálásuk azonban alkalmazkodik a tájképi érzékelési távolsághoz: a budai oldalról nyugodt, értelmezhető városias környezetet láttatnak. Egyenletes beépítésük külön hangsúlyt ad a Rákóczi híd előtti végpontként formált Nemzeti Színház és Müvészetek Palotája együttesének. A Nemzeti Színház beépítése alapelveiben jó. A parti sétány és a kialakított park a föhomlokzat előtt városépítészeti kontextust teremt az addigi senki földjén. Az épület befordított tengelye a Duna kanyarulatát egy új városi pontként definiálja, a látogatók számára a város egy új, eddig kevéssé ismert dunai perspektíváját kínálja. Az épület az anakronisztikus építészeti formanyelv ellenére tagoltságában alkalmas arra, hogy tájépítészeti léptékben érzékelhető legyen.

A magán ingatlanfejlesztés az ezredforduló után fedezte fel a Duna-partokat. A kerületek egymással versengtek a fejlesztők kegyeiért. Manhattan-szerü beépítési tervek születtek, függetlenül a főváros gazdasági teljesítőképességétől. A gazdasági válság betöréséig a tervek közül csak néhány készült el, elsősorban az angyalföldi partszakaszon. A parti fák koronája fölé itt hamarosan iroda- és lakótömbök emelkedtek. A budapesti hagyományhoz híven az építészeti és a tájépítészeti (landmark!) formálás érvei csaptak össze, sokszor éppen a rossz kompromisszumot eredményezve. Az ingatlanfejlesztés logikája ott is az egyre magasabb, szabadon álló, tömbszerü formálás felé szorította az építészeket, ahol a szabályozási terv eredetileg zártsorú beépítést írt elő, mint a Marina-part esetében. Építészetileg és városépítészetileg sikeres példaként szinte csak a Graphisoft tekinthetó, ahol az alacsony beépítés a Dunától visszalépve tiszteletben tartja a part funkcióit és zöld karakterét.

\section{TÉRÉRZÉKELÉS VÁROSI LÉPTÉKBEN}

A városépítészeti befogadást jellemezve már Pogány Frigyes elemezte a háromdimenziós érzékelés sajátos jelenlétét: „A város egy-egy motívuma igen sokszor ilyen egyszerü rátekintéssel feltárulhat a szemlélő előtt. ... Általában ilyen módon, mintegy síkszerüen bontakozik ki szemünk előtt a távoli városok képe is, amikor a színes foltok, tónusértékek és körvonalak alkotják a festői jellegü kép elemeit, s a mélységi dimenzió - a tömeg- és térhatás - még nem lényeges. E síkjellegü motívumok - közeledésünk folyamán fokozatosan testet öltenek, szétszóródnak, térbe tagolódnak. Ha a város épületei körülvesznek bennünket, a körültekintés bonyolultabb szemléleti folyamatában a fejlettebb egységek, az utcák, terek esztétikai hatása bontakozik ki. Ekkor már a müfaj különleges eszközei, a térhatás és a tömeghatás gazdag módosulásai játszanak közre az esztétikai élmények kialakulásában. Ezek a hatások a fényképen már nem érvényesülnek. A belső városképben a térbeli jellegből adódó hatások minden lehetősége kiaknázható."19

\footnotetext{
${ }^{19}$ Pogány 1954. 7.
} 
Mint látjuk, Pogány Frigyes a külső városképet - a mi szóhasználatunkban a tájképi érzékelés távolságát - kétdimenziósnak tekintette, és a térhatás és tömeghatás müködését csak városépítészeti léptékben elemezte. A budapesti dunai látkép egyedülállósága azonban, hogy a mélység dimenziói tájképi léptékben is megjelennek. A mélység érzékelése különleges gazdagságot ad a városkép élményének. Hogy kihasználhassuk ennek előnyeit a városképben, ismernünk kell a térérzékelés alapjait.

A tér érzékelése az egyedfejlődés során felbecsülhetetlen fontosságú volt. A pontos orientációhoz több érzékszervünk járul hozzá. Ebben a tanulmányban csak a látás térérzékelő mechanizmusait elemezzük, egyrészt mert átlagos helyzetben a látás szállítja messze a legtöbb információt a térérzékeléshez, másrészt mert a többi érzékszerv érzékelése a városi léptékekben kisebb jelentőséggel bír.

James Gibson pszichológus az ötvenes években a látás percepcióját kutatva 13 olyan „,perspektívá”-t írt le, amelyek segítségével megbecsülhetjük a körülöttünk lévő világ elemeinek önmagunkhoz és egymáshoz viszonyított helyzetét, azaz érzékelhetjük a téri viszonyokat. ${ }^{20}$ A teret érzékelve mindezekböl a perspektívákból az adott helyzetnek megfelelően párhuzamosan nyerünk információkat, amelyekből öröklött és tanult módon állítjuk össze a környezet tér-képét.

A távolsági információk ezen forrásainak egy része olyan, amely a festészet fejlödéstörténetéből ismerős, mint a takarásnak, a körvonalak folytonosságának, a környezeti elemek egymáshoz viszonyított méretének, az árnyékhatásoknak felhasználása a tér érzékeltetéséhez. A reneszánsz festészet használja először a vonalas egyvagy kétfókuszú perspektívát, amit a barokk fejleszt tökélyre a trompe l'oeil falfestészetben. Az impresszionizmus tájképein jelenik meg a textúraperspektíva és a légperspektíva használata, amely a tájképábrázolás mélységérzékeltető eszközévé válik. Ezek azok a perspektívák, amelyeket a megfigyelő egy statikus nézőpontból, egy távolságra fokuszálva, akár fél szemmel is érzékel (statikus monokuláris jelzőmozzanatok) és a térérzet kialakításához felhasznál. Az előbb említett korlátok teszik lehetővé, hogy ezeket a perspektívákat a klasszikus festészet is fel tudta használni. Ugyanezen korlátok viszont azt is eredményezték, hogy a festmények sohasem lettek valóban háromdimenziósak. A 19. század fedezte fel a szemnek azokat a belső müködéseit, amely a finomabb mélységérzékelést lehetővé teszik: a szem fokuszálását és a sztereoszkopikus látást. A fényképezés fejlődése sokban lemodellezte a szem fokuszáló működését. Először a művészi fényképezés, onnan átvéve pedig a festészet újabb eszközévé vált az éles és életlen képrészletek használata a közeli és távoli megkülönböztetésére.

Az igazi felfedezés azonban a sztereoszkopikus látás - Gibson szóhasználata szerint a binokuláris perspektíva - volt. A két szem egy adott tárgyról két különböző képet közvetít az agyba, minél közelebb van a tárgy, annál nagyobb a két kép közti különbség. Az adott tárgyra való fokuszáláshoz ráadásul a két szem tengelye a távolságtól függő szögbe áll be. A csecsemő agya az első hetekben megtanul egyetlen érzékelt képet szintetizálni a bejövő két különböző képből (binokuláris látás), az első

\footnotetext{
${ }^{20}$ Gibson 1950 .
} 
hónapokban pedig a képek különbségéből, a fokuszálás izomfeszültségéből (akkomodáció) és a szemtengelyek által bezárt szögből (konvergencia) megtanulja a mélységre vonatkozó információ előállítását is. A tanulás először az elérhető testtérre vonatkozik - a csecsemő kitartóan próbálkozik saját lábának vagy az elé függesztett tárgynak az elérésével. A mozgás fejlödésével párhuzamosan nő a megbecsülhető távolságok nagysága. A binokuláris látás, pontosabban a két különböző képböl szintetizált kép a térhatású ábrázolás alapjává vált a 19. század szalonjainak sztereoszkópjaitól a mai 3D-s mozikig. Az így előállított kép akkora ugrást jelent a térérzékelés fejlődésében, hogy Gibson munkásságáig a tudományban is, a köztudatban pedig máig a térlátás legfontosabb alapjának tünik a sztereoszkopikus látás.

És ez így is van. A közvetlen környezetünk pontos érzékeléséhez, és az azzal adekvát fizikai reakcióinkhoz, mozgásunk koordinálásához alapvető a sztereoszkopikus látás. A proxemika személyes, illetve társasági távolságként definiált tartományában elsődleges ez a térlátás: lehetővé teszi, hogy a kommunikációs partner testtartását, mozdulatait, mimikáját pontosan érzékelve képet alkossunk érzelmeiről, szándékairól. Ezen a távolságon túllépve azonban elveszíti a jelentőségét. Az érzékelőtől 5-6 méteren túl lévő tárgyakra fokuszálva a két szem által közvetített képek közötti különbség, az akkomodáció és a szemtengelyek szögének különbsége is annyira kicsi lesz, hogy az agy egyre kevésbé tudja távolsági információk generálására felhasználni. Körülbelül az általunk építészeti távolságként definiált tartományban veszik el a binokuláris látás jelentősége a térérzékelésben.

A városképek érzékelésében ezért részben azokra a térérzékelési perspektívákra hagyatkozunk, amelyeket a festészet fejlődéséből ismerünk. Az érzékelés távlatától és az érzékelt környezet jellegétől függően természetesen más és más perspektíva kerülhet előtérbe a térérzethez szükséges információk szállításában. Minél szabályosabb egy városi szövet és minél inkább épített jellegü, annál nagyobb szerepet kap például a vonalas perspektíva, az építészeti és a városépítészeti érzékelés tartományában. A légperspektíva viszont csak kellően nagy távolságok, azaz a tájképi érzékelés távlatában hordoz információt.

A nagyléptékủ városképekben speciális jelentőséget kapnak a látott elemek méretének, megvilágítottságának, textúrájának, élességének különbségei. A textúragradiens változásaiból az érzékelő nagy pontossággal megállapíthatja a látott felületek távolságát, dőlésszögét, ${ }^{21}$ ezen a módon érzékeljük például egy beépített táj domborzatát. Minél nagyobb különbségeket látunk ezeken a területeken az adott városképben, annál szélesebb skálán mozog az érzékelés távlata, befogva a lehetőségeket a személyestől az építészeti és városépítészeti távlaton át a tájképi érzékelés távlatáig. Minél több lépték van jelen az adott városképben, annál mozgalmasabbnak érzékeljük azt. Ez a magyarázata Budapest dinamikus látképének. A budapesti dunai városkép egyedülállósága szoros összefüggésben van a folyam keresztmetszeti méretével, amely nemcsak behozza a tájképi távlatot a városképbe, de élesen ütközteti is azt az építészeti és városépítészeti távlatban érzékelt részletekkel.

${ }^{21}$ Gibson 1950. 
Nagy távlatokban a tér élményszerüségét ugyanis a részletezettség, élesség, megvilágítottság, textúra hirtelen váltása, szakadása okozza a látványban. Ez a szakadás okozza a szakadék peremén álló térélményét - és esetleges félelmét - a dombtetőn állóéval szemben, noha adott esetben ugyanolyan mélységbe tekintenek alá. Egy alpesi tájat szemlélve jóval több ilyen szakadást érzékelünk, ezért a tájat mozgalmasabbnak, változatosabb térélményt nyújtónak érzékeljük, mint az Alföld látványát, ahol a fenti tényezők folyamatosan, fokozatosan változnak. A budapesti látképben is a budai hegyek okozzák a mozgalmasság, a téri komplexitás érzését, esetlegesen felerösítve a pesti oldal nyugalmas kontrasztjával.

Mindeddig nem beszéltünk azonban a városszövet érzékelésének egy nagyon fontos aspektusáról, a befogadó mozgásáról. Statikus képként, illetve statikus képek összegeként szemléltük a városképet. A térérzékelés egyik meghatározó módja, a parallaxis perspektíva azonban a néző mozgásához kötődik. Mozgásunk közben a látott képben az egymáshoz mérten mozdulatlan elemek észlelt nagysága és egymáshoz viszonyított távolsága is változik, amiből az agyunk távolságot következtet, azaz teret érzékel. Mindnyájunknak ismerős ez a jelenség, például vonatablakból kitekintve. Saját nézőpontunk mozgásával a látványban érzékelt részletek megmozdulnak.

\begin{tabular}{|c|c|c|c|c|c|c|c|}
\hline & $\begin{array}{c}\text { Bizalmas } \\
\text { távolság } \\
0-0,5 \mathrm{~m}\end{array}$ & $\begin{array}{c}\text { Személyes } \\
\text { távolság } \\
0,5-1,2 \mathrm{~m}\end{array}$ & $\begin{array}{c}\text { Társasági } \\
\text { távolság } \\
1,2-3,6 \mathrm{~m}\end{array}$ & $\begin{array}{c}\text { Nyilvános } \\
\text { távolság } \\
3,6-10 \mathrm{~m}\end{array}$ & $\begin{array}{l}\text { Építészeti } \\
\text { távolság } \\
10-50 \mathrm{~m}\end{array}$ & $\begin{array}{l}\text { Város- } \\
\text { építészeti } \\
\text { távolság } \\
50-150 \mathrm{~m}\end{array}$ & $\begin{array}{l}\text { Tájképi } \\
\text { távolság } \\
>150 \mathrm{~m}\end{array}$ \\
\hline Tapintás & & & & & & & \\
\hline Szaglás & & & & & & & \\
\hline Hallás & & & & & & & \\
\hline Akkomodáció & & & & & & & \\
\hline Konvergencia & & & & & & & \\
\hline Sztereolátás & & & & & & & \\
\hline Takarás & & & & & & & \\
\hline Méret & & & & & & & \\
\hline Árnyékolás & & & & & & & \\
\hline Vonalas perspektíva & & & & & & & \\
\hline Textúragradiens & & & & & & & \\
\hline Levegő-perspektíva & & & & & & & \\
\hline Alapsík emelkedése & & & & & & & \\
\hline Mozgás-parallaxis & & & & & & & \\
\hline
\end{tabular}

jelentéktelen

jelentős

2. ábra. A térbeli információk jelzőmozzanatainak közelítő jelentősége az urbánus térben a távolsági tartománytól függően 
A közeli villanyoszlopok - építészeti távlat elemei - gyorsan rohannak hátrafelé, a messzebb álló farm épülete - városépítészeti távlat - lassabban jön szembe, míg a távoli hegyek - tájképi érzékelés távlata - velünk együtt látszanak haladni.

Kisebb sebességgel és kisebb távlatokkal kevésbé feltűnő ez a térérzékelési mód, de téri tájékozódásunkban folyamatosan használjuk, elsősorban azokban a távolságokban, ahol a sztereoszkopikus látásnak már kevés hasznát vesszük. Még csak fel sem kell hozzá állni a székről: elég, ha a fejünket megmozdítjuk.

Ahogy a közeli távolságoknál a binokuláris perspektíva, úgy a nagyobb távlatoknál a parallaxis perspektíva okozza a leginkább élményszerủ térérzetet. Nem véletlen, hogy a filmművészet a kezdetektől kihasználta a schwenkek lehetőségét, emelve a filmbéli kulissza valóságosságát. Minden 3D-s attrakcióban is bőven látunk olyan jeleneteket, ahol a kamera valami mozgó szemszögből láttatja a nagy távlatokkal rendelkező világot, például az ürhajóból a csillagok előtt elsuhanó Földet. A valóságban minél gyorsabb a befogadó mozgása, annál érzékletesebbé válik az élmény. Erre alapszanak az autópályák mellett elhelyezett, három dimenziót láttató óriásplakátok, amelyek gyalogos sebességnél nem mủködnének (2. ábra).

\section{A VÁROSKÉP „FOGYASZTÓI”}

A városkép védelmének szabályozásakor elengedhetetlen a „fogyasztó” mennyiségének és szempontjainak figyelembevétele. Kik, honnan, mennyien és hogyan nézik a dunai panorámát? A városkép hagyományos elemzése a nézelődő, sétáló ember, a flaneur szemszögét tekintette elsődlegesnek. Sitte azt a városképi részletet tekintette esztétikai szempontból formálandónak, amelyet a szemlélő egy helyben átlát. Granasztói Pál és Pogány Frigyes már felvetik a közlekedési eszközről érzékelt város kérdését, azonban ezt, mint nem jellegzetest elvetik: „A városesztétikai vizsgálódásnak főként azokra a nézőpontokra kell korlátoznia magát, amelyek a legáltalánosabbak, a leggyakoribbak, a leglátogatottabbak, amelyekröl naponta, évente, sőt évszázadokon át a legtöbben látják a várost vagy egy-egy részét." ${ }^{22} \mathrm{~A}$ sétatudomány fejlődése nem utolsósorban a motorizált városi lét ellenében született meg, ezért, bár a bicikliröl, jármüből való városérzékelés jelentőségét többen is hangsúlyozzák, ${ }^{23} \mathrm{a}$ kidolgozott metodológia elsősorban a sétáló ember szemszögéből való elemzésre koncentrál. Meggyesi Tamás azonban már a promenadológia speciális esetének tekinti a különböző eszközökkel való utazást és a város érzékelését a különböző eszközök által nyújtott lehetőségek szerint. ${ }^{24}$

Történetileg a budapesti dunai látkép esetében is igaz a gyalogos, mint befogadó, elsőbbsége. A Lánchídon 1875-ben majd tízmillió gyalogos kelt át, az akkori város lakosságának mintegy hússzorosa. A gyalogos átkelők száma a további hidak fel-

\footnotetext{
${ }^{22}$ Granasztói-Pogány 1960. 142.

${ }^{23}$ Meggyesi 2012. 33-34, Granasztói-Pogány 1960. 142, 149-150.

${ }^{24}$ Meggyesi 2012. 33, 34.
} 
épültével tovább nőtt a harmincas évekig, amikor a négy hídon (Lánchíd, Erzsébet híd, Szabadság híd és Margit híd) összesen 33,6 millió fő kelt át gyalogosan (1931), azonban ekkor a villamoson vagy buszon átkelök létszáma már 100 millió fölött volt. ${ }^{25}$ A hidak kezdetben nemcsak a célirányos gyalogos közlekedés helyszínei voltak, de kedvelt sétahelyek is, már csak a pormentes séta lehetősége miatt, ami ritkaság volt az akkor még parkokban szükölködő fővárosban. A hidak nemcsak új látványelemek voltak a városképben, de új nézőpontot is nyújtottak, a folyó kettős ívét követő ritmusuk miatt más és más szögből megmutatva a várost. A hidak építői mindig is tudatában voltak ennek az attrakciónak. Amikor Vásárhelyi Pál 1832-ben új hídra tett javaslatot a Margit-szigettől délre, a híd közepére kilátóteraszt tervezett, mint írta „szép kilátással és reumával”. ${ }^{26}$ A rakpartok is gyorsan váltak kedvelt sétahelyekké, bár igazán intenzív városi élet máig csak a pesti Korzón alakult ki, ahol a budai Vár látványa szolgált attrakcióként.

Az arányok azonban a második világháború után a közösségi közlekedés fejlesztésével még gyorsabban változtak. 1965-ben az említett négy híd már csak 10,7 millió gyalogost számolt, míg villamossal majd 170 millióan, busszal 144 millióan keltek át a budapesti hidakon. Ugyanebben az időben kezdődött meg a hidak gépjármüforgalmának emelkedése. Míg 1931-ben mintegy 10 millió közúti gépjármü haladt át a hidakon, addig a rendszerváltáskor már 142 millió, 2002-ben pedig 220 millió. ${ }^{27}$ Mindent egybevetve a 2002-es forgalomszámlálás szerint a hidakon áthaladóknak ma elenyésző része érzékeli „flaneur”-ként a dunai panorámát.

A jármüvel valamely hídon átkelő számára a Dunával való találkozás időtartama nagyon rövid: a forgalomtól, sebességtől függően általában 2-3 perc. Ez alatt az idő alatt játszódik le a látvány feltárulása, a tájépítészi lépték domináns megjelenése, majd újbóli eltünése. A panorámát behatárolja a jármü ablaka vagy az utasok jármüvön belül elfoglalt pozíciója. Ugyanezek a korlátok azonban fel is erősítik a hatást. A hidakon jármüvel átkelők természetesen többségükben nem tudatosan érzékelik a folyóval való találkozást - a vezetésre koncentrálnak, olvasnak, beszélgetnek stb. -, de számukra is érzékelhető a váltás, hiszen éppen a periferiális látás különösen érzékeny a látótéri elemek mozgására, a fényviszonyok változására. Mindezek miatt a budapestiek többségének mentális térképén a legfontosabb orientációs elem a Duna, amely tagolja az ismert útvonalakat, információt szolgáltatva a városon belüli pozícióról.

A gyalogosok és jármüvek aránya sajnos hasonló a Duna-partok esetében is. Jelentősebb gyalogos forgalom ma csak a pesti korzó szakaszán van kellemes nyárestéken. A partokon közlekedők nagyobb csoportja a hévek és villamosok ablakából, legnagyobb része pedig a rakparton haladó gépkocsikból érzékeli a városképet. Ma még kisebb, de folyamatosan növekvő a budai parti bicikliutat használók létszáma. A Dunával párhuzamosan közlekedők pozíciója jellegzetes: míg az egyik oldalon a

\footnotetext{
${ }^{25}$ Gáll 2005. 18.

${ }^{26}$ Gáll 2005. 28.

${ }^{27}$ Gáll 2005. 18.
} 
jármü, illetve az épített környezet szüken határolja le az érzékelt teret, addig a másik oldalon a látvány kinyílik; építészeti, városépítészeti és tájképi elemei folyamatosan változó szögben és viszonyban jelennek meg. A parallaxis perspektíva itt erősíti fel leginkább a városkép térbeliségét.

Összességében a mai városhasználók Dunáról alkotott képében meghatározó a parallaxis perspektíva által nyújtott térélmény, amihez az elötér, középtér és háttér, azaz az építészeti, városépítészeti és tájképi távlatok folyamatos együttes jelenléte szükséges a látványban.

\section{A TANULSÁGA A DUNAI LÁTKÉP ÉRZÉKELÉSÉNEK A MAI SZABÁLYOZÁSRA?}

A Duna-part szabályozásában természetesen számtalan szempont felmerül, a kiemelt ingatlanfejlesztési potenciál kiaknázásától a használható közterületek kialakításán keresztül a környezetvédelmi szempontokig. A panoráma, a városkép esztétikája kiemelt szempont lehet a város külső és belső identitásában játszott szerepe miatt. Ez a tanulmány a városkép vizuális érzékelésének elemzése alapján csak arra szorítkozik, hogy a szabályozás látványra gyakorolt hatását értékelje és ebben az irányban javasoljon változtatásokat.

Milyen területek játszanak szerepet a budapesti dunai panoráma szabályozásában? Számtalan területi definíció lehetséges, mint például az utcaszerkezethez alkalmazkodó, amit a jelenlegi szabályozás alkalmaz, vagy a történeti rétegekből kiinduló, amelyen a világörökség területének lehatárolása alapszik. A látványelemzés alapjául leginkább alkalmasnak a beláthatóság kritériuma bizonyul. Camillo Sitte szerint a városban művészi formálás tárgya az a városrészlet, amelyet a szemlélő tekintetével egyszerre átfog, egy pontból érzékel. ${ }^{28}$ Ezt a definíciót kissé továbbfejlesztve és kiterjesztve a dunai városképnek mindazon közigazgatási területen belüli városképek összességét tekinthetjük, amelyekben a Duna vize része a látványnak. Ezek között a városképek között természetesen „előkelőbb”, nagyszabású látványok is szerepelnek, mint a Citadella tövéből, a budai várból, a Margit hídról vagy a pesti korzóról feltáruló városképek, csakúgy, mint szerényebb városképek. A parallaxis perspektíva jelentősége miatt kiemelten kell kezelni azt a látványt, amely a rakpartokról, illetve a hidak forgalmi magasságából feltárul. Annak ellenére, hogy végtelen számú ilyen városkép létezik, a városnak azon területe, amely ezeken a képeken szerepel, könynyen modellezhető és térképezhető viszonylag kevés fotografikus adatfelvétel alapján. Ez a terület adja a dunai panorámát védő építési szabályozás elsődleges célterületét.

A Duna-parti beépítés nehéz feladat: akkor járunk jól, ha a szabályozás mindazon léptékek követelményeit egyesíti, amelyek az adott pont rálátásában érvényesülnek vagy érvényesülhetnek. Mindehhez a beépítendő telekhez vagy partszakaszhoz kap-

${ }^{28}$ Sitte 1889. 
csolódóan ki kell szerkeszteni és el kell választani azokat a területeket, ahonnan az építészeti, városépítészeti vagy tájépítészeti távolságban érzékelhető. Ezeknek a területeknek a nagysága, pontosabban a felhasználói fontossága alapján kell meghatározni a beépítés kötelező paramétereit. A kiszerkesztett térképeken azt fogjuk tapasztalni, hogy a mai városszerkezetben a tájképi távlatok szerepe meglepően nagy, az újonnan fejlesztendő Duna-partok esetében szinte kizárólagos. A szabályozást azonban nem feltétlen a mai felhasználáshoz, hanem a - reálisan - tervezett városfejlödéshez kell igazítanunk. A szabályozás hagyományos eszköztára elsősorban az építészeti és városépítészeti léptékre kínál bejáratott módozatokat. A tájképi léptékü formálás szabályozási eszközeit nekünk szükséges kigondolnunk.

A felmerülő feladatok között jellemzően eltér a történeti belváros dunai látképének védelme a külső partszakaszok fejlesztésének kérdéseitől.

A történeti belváros dunai látképének védelme magától értetődik, és az építészek és a közönség körében is általános a mai sziluettből kiemelkedő új elemek elutasítása. A történeti belváros Duna-partjának fejlesztése a nemzetközi példákat is figyelembe véve a motorizált közlekedés csökkentését, a városi sétára, tartózkodásra alkalmas közterületek bővítését, a város és a folyam közvetlen kapcsolódásának megteremtését jelenti. Mindehhez jó eszközt ad a történeti rakpartok megújítása, azonban a múemléki védelem és az árvízvédelmi szintek emelkedése egyes helyeken ellentmondásba kerülhet a korszerủ városépítészeti elvekkel és gyakorlattal. Szükséges megtalálni azokat a műszaki megoldásokat, amelyek lehetővé teszik a közvetlen kapcsolat fenntartását (illetve kialakítását). A Duna-part és a hidak gyalogos visszahódítása felértékeli az építészeti és a városépítészeti érzékelést, ezért a mütárgyait építészeti igényü formálással és részletgazdagsággal kell kialakítani. Jó példa erre a Margit híd megújítása, amely - a historizáló formanyelv ellenére - méltó helyre emelte a hidat a városképben.

A Duna külső szakaszain, a volt ipari vagy zöld felületek átalakításával létrejövő új fejlesztések azonban felvetik a kérdést, hogy milyen jellegü Duna-partot akarunk megteremteni. Itt ma csak a tájképi látvány érvényesül és a sík táj nem segíti elő a tér érzékelését. Ebben a helyzetben egyes esetekben indokolt lehet az épületek, építmények tájképi formálása, aminek jó példája a Megyeri híd. A landmark jellegü formálás azonban csak akkor érvényesülhet, ha annak hangsúlyai, ritmusa tájképi léptékben tervezett, és elemei karakteresek, de nem rivalizálnak egymással. A horizontális látvány miatt a tájkép hangsúlyos elemévé válhatnak az árvízvédelmi müvek, amelyek kellö formálás híján ipari csatornává változtathatják Dunánkat. A hagyományos várossziluett védelmében sokan a partok zöld jellegének megtartását látnák szívesen, aminek szabályozástechnikai megvalósítása egyszerü: pusztán a parti zöld sáv védelméröl vagy telepítéséről kell gondoskodni kellő szélességben, valamint a mögöttes beépítési magasságot a lombkoronaszint alatt tartani.

Ennél bonyolultabb megoldás azonban, ha valódi várost akarunk építeni, amelyben az építészeti, városépítészeti és tájképi távlat gazdag egymásra hatásban érvényesül. A városépítészeti formáláshoz ezen a területen létre kell hozni azokat a téri, közterületi struktúrákat, amik lehetővé teszik a városépítészeti nézöpont érvényesü- 
lését. Példaként lebeghetnek elöttünk a Szajna-part új fejlesztései, de akár az Újlipótváros is.

A külső kerületek Duna-partjai az ingatlanfejlesztések célterületei lesznek az ökológiai helyzet értéke és a közlekedés fejlődése miatt, de Budapest gazdasági-demográfiai folyamatai miatt nem valószínủ minden ma tervezett projekt megvalósulása, minden szabályozott terület beépülése. A város népességének és gazdasági erejének fogytán, a fenntartható város célját szem elött tartva megfontolandó és városi szinten szabályozandó, hogy hol és milyen mennyiségben hozhatók létre új urbánus szövetek. Az új ingatlanfejlesztések koncepciójában a megőrzött táji és születő építészeti elemek mellett meg kell formálni a városépítészeti léptékủ struktúrát ahhoz, hogy az új negyedekben a belvároshoz hasonlóan gazdag városi környezet és Duna-parti élmény jöhessen létre. A gyorsabban átépülő és a továbbra is extenzív felhasználású területek fejlesztése közös szempontjának kell lennie, hogy ezek a Duna-partok a budapestiek rekreációjának a budai hegyekkel egyenértékü övezetei. A partok fejlesztésénél ezért biztosítani kell a még megmaradt természetes partok, zöldfelületek védelmét, a védmüvek természeti jellegét, a parti gyalogos-, és bicikliutak, terek közvetlen kapcsolódását a folyamhoz és a tájhoz.

\section{IRODALOMJEGYZÉK}

Benkő Melinda: Duna-party. Régi-Új Magyar Épitőmüvészet - Utóirat 49 (2009) 12-16.

Berza László (szerk.): Budapest Lexikon. Akadémiai Kiadó, Budapest 1993.

Cullen, Gordon: Townscape. The Architectural Press, London 1961.

Gáll Imre: A budapesti Duna-hidak. Hídépítő Rt., Budapest 2005.

Garay, Márton - Benkő, Melinda: Between Waterway and Railway - Industry along the Danube Riverside in Budapest. Periodica Polytechnica Architecture 45 (2015) 53-58.

Gibson, James J.: The Perception of the Visual World. Houghton Mifflin, Boston 1950.

Granasztói Pál: Budapest városépítészeti arcképe. In: Granasztói Pál (szerk.): Budapest arculatai. Szépirodalmi Könyvkiadó, Budapest 1980.

Granasztói Pál - Pogány Frigyes: Városépítészet. In: Granasztói Pál (szerk.): Város és épitészet. Műszaki Könyvkiadó, Budapest 1960.

Hall, Edward T.: Rejtett dimenziók. Gondolat, Budapest 1987.

Kissfazekas, Kornélia - Illyés, Zsuzsanna - Gurdon, Balázs: Isolated Islands? Periodica Polytechnica Architecture 45 (2015) 59-66.

Kolundzsija Gábor: A rakodópart kövei. http://epiteszforum.hu/a-rakodopart-kovei1, (Utolsó megtekintés: 2015. 04. 05.)

Lynch, Kevin: The Image of the City. MIT Press, Cambridge 1960.

Meggyesi Tamás: Promenadológia - fejezetek a lineáris látványelemzés elméletéhez. Kézirat, Budapest 2012.

Pálfy Sándor - Sólyom Benedek - Fialovszky Tamás: Budapesti Duna-partok karaktervizsgálata. Kézirat, Budapest 2014.

Pogány Frigyes: Terek és utcák müvészete - történeti áttekintés. Építésügyi Kiadó, Budapest 1954.

Preisich Gábor: Budapest városépitésének története - Buda visszavételétöl a II. világháború végéig. Budapest 2004.

Romaniak, Alicja - Skaliczki, Judit - Szabó, Árpád: Strategies Resolving Spatial Fragmentation: Case Study in the Brownfield Zone of Budapest. Periodica Polytechnica Architecture 45 (2015) 67-74. 
Sekuler, Robert - Blake, Randolph: Észlelés. Osiris Kiadó, Budapest 2004.

Sitte, Camillo: Der Städtebau nach seinen Künstlerischen Grundsätzen'. Wien 1889.

Szabó Julianna: Budapest nemzetközi szerepkörei és a várospolitika 1989-2009 - Meg nem valósult rendezvények megvalósult hatásai. In: Barta Györgyi - Keresztély Krisztina - Sipos András (szerk.): A világváros Budapest két századfordulón. Napvilág Kiadó, Budapest 2010. 331-348.

\title{
ROLE OF THE PERSPECTIVES IN SPATIAL PERCEPTION IN BUDAPEST'S DANUBE CITYSCAPE
}

\begin{abstract}
Summary
This study, based primarily on the tradition of Pál Granasztói and Frigyes Pogány, but expanding them in space and dynamics, taking into account the visual perception theories developed in the meantime and the actual characteristics of users, aims to analyse on four levels the Budapest skyline's development:

Based on the physiology of vision and proxemics analogy, it introduces in the city the concept of architectural, urban and landscape sensing, defining their distances and describing their characteristics. It analyses the build-up of the river banks depending on the different sensory perspectives.

Based on the spatial perception psychology and physiology, it analyses the main sources of information playing a role in urban in depth perception, depending on the perspective. It emphasizes the main information sources in the Budapest skyline perception.

Based on historical and contemporary traffic data, it describes the primary target group of users on the Danube banks.

Through all this outlines the requirements in front of the traditional architectural regulation of Danube coast, considering the historic riverbanks as well as facing the further developments.
\end{abstract}

Keywords: Budapest, the Danube, architecture, cityscape, landscape, proxemics, spatial perception 